\title{
Isolation and cryopreservation of adipose tissue derived stem cells from different adipose tissues in obese patients
}

\author{
FREITAS, D. M. B. ${ }^{1}$, AGUiAR, A. M. ${ }^{2}$, JANZ, F. L. ${ }^{3}$, MILlÉO, F. Q. ${ }^{4}$ and \\ FAVERO, G. M. ${ }^{1 *}$
}

\author{
${ }^{1}$ Laboratório de Anatomia, Universidade Estadual de Ponta Grossa - UEPG, Campus de Uvaranas, \\ Av. General Carlos Cavalcanti, 4748, CEP 84030-900, Ponta Grossa, PR, Brazil \\ ${ }^{2}$ Laboratório de Biologia Básica de Células-tronco, Instituto Carlos Chagas, Fundação Oswaldo Cruz - Fiocruz, \\ Rua Professor Algacyr Munhoz Mader, 2135-2261, CEP 81310-020, Curitiba, PR, Brazil \\ ${ }^{3}$ Faculdade de Medicina, Universidade de São Paulo - USP, CEP 01246-903, Av. Dr. Arnaldo, 455, \\ São Paulo, SP, Brazil \\ ${ }^{4}$ Instituto de Pesquisa Aplicada em Medicina - INSPAM, CEP 84040-130, R. Nestor Guimarães, 281, \\ Ponta Grossa, PR, Brazil \\ *E-mail: gmfavero@uepg.br
}

\begin{abstract}
Introduction: Adult stem cells (ASCs) are a population of tissue-resident cells that have the capacity for self-renewal and differentiation into different cell types with potential for cell therapies. New approaches for ASCs isolation, including many tissue sources and new protocols that are more effective and less expensive are under investigation. Thus this work aim is to isolate, maintain in cell culture and evaluate cryopreservation protocols for adipose derived stem cells (ADSCs) from different tissues such as subcutaneous adipose tissue, visceral mesenteric and omental visceral taken from the same individual. Material and Methods: The techniques of mechanical and enzymatic dissociation were used, in order to investigate the most appropriated method to ADSCs isolation. Dimethylsulfoxide (DMSO) and dimethylformamide (DMF) in different concentrations were tested as cryoprotectors in 24, 48 and 72 hours thawing protocols. The samples were collected from obese patients with associated diseases undergoing bariatric surgery, between 30 to 45 years old. Results: Among 10 collected samples it was possible to measure cell viability from 4 patients. The higher cell rate was obtained from the visceral tissue of omentum. Conclusion: DMSO was the more efficient cryopreservant for this condition. This adipose tissue source could be explored for ADSCs isolation and future clinical investigations.
\end{abstract}

Keywords: adult stem cell, adipose tissue, obesity, cryopreservation.

\section{Introduction}

Human adult stem cells (ASCs) represent a population of multipotent stem cells that are easily expanded in culture and can serve as precursors for the generation of a variety of hematopoietic (hematopoietic stem cells; HSCs) and nonhematopoietic tissues (mesenchymal stem cells; MSCs), including bone, cartilage, muscle, and fat elements (CAPLAN and DENNIS, 2006). MSCs represent a very attractive tool for developing new strategies for clinical applications based on cell therapy. These cells have been successfully isolated from various tissues such as bone marrow, amniotic fluid, umbilical cord, decidual tooth (SAKAGUCHI, SEKIYA, YAGISHITA et al., 2005; ABDALLAH and KASSEM, 2008).

Adipose tissue plays an active role in metabolic homeostasis and functions as a central endocrine organ. Although chiefly composed of adipocytes, it is acknowledged that adipose tissue is also a significant reservoir of mesenchymal stem cells, termed adipose-derived stem cells (ADSCs). Among the different sources of MSCs already described, the adipose stem cells have attracted the attention of many scientists and physicians due to the frequently large amounts of subcutaneous adipose tissue that can be easily harvested using liposuction and dermolipectomy procedures, many times associated with bariatric surgery or esthetics procedures (ZUK, ZHU, ASHJIAN et al., 2002).

White adipose tissue is mainly divided into two fat depots: internal or visceral and subcutaneous. In humans, a major contribution of visceral adipose tissue to the development of insulin resistance and to the cardio-metabolic complications in obesity was proposed (TODA, UCHIHASHI, AOKI et al., 2009). The differences observed between visceral and subcutaneous adipose tissues are supported by studies showing that visceral and subcutaneous fat depots exhibit differential gene expression profiles (ROGER, MEACHAM, OEFFINGER et al., 2005). Some authors assume that the visceral fat depot is associated with metabolic syndromes, while subcutaneous fat has a metabolic buffer function. Moreover, several studies have found that the adipogenic and osteogenic differentiation potential in culture varies for ADSCs derived from subcutaneous fat versus the omentum (KATZ, THOLPADY, THOLPADY et al., 2005).

Lipid accumulation is not the only trigger for the development of obesity. One of the most important discoveries regarding the development of obesity was the description of the establishment of an inflammatory state characterized by an increase in the levels of local and systemic inflammatory cytokines and macrophage 
infiltration into subcutaneous adipose tissue (AHIMA and FLIER, 2000). Once a disruption in adipose tissue homeostasis begins, the metabolic buffer function of subcutaneous adipose tissue and ADSCs profile could be changed (BLAGLIONI, CANTINI, POLI et al., 2012). Moreover, there are few studies regarding to the evaluation of ADSCs from different tissues from the same donor with obesity (BAPTISTA, SILVA, PEDROSA et al., 2013). Besides, another important feature to be evaluated is the ADSCs cryopreservation. The choice of an ideal cryoprotectant is indispensable so that obtained cells can be stored for future applications.

Then, the aim of this work was the analyses isolation, expansion and cryopreservation of ADSCs derived of different tissues from obese patients in order to assess whether it is the more feasible adipose source for ADSCs propagation and storage.

\section{Materials and Methods}

\subsection{Samples collection}

Ten patients submitted to bariatric surgery (vertical gastrectomy type with ileac interposition) were selected for this study at the Vicentino Hospital - St. Camilo Unity, Ponta Grossa, Brazil. According to WHO guides, all patients (females and males aged between 30 and 45 years) were obese (grade II and III) associated with comorbidities (hypertension, dyslipidemia, diabetes type II, apnea and others). All patients signed the informed consent and all protocols in this investigation were previously approved by the Ethics Committee on Human Research of the State University of Ponta Grossa, number: 189893, 04/02/2012.

At the moment of surgery about 1 to $10 \mathrm{~g}$ of subcutaneous fat, visceral fat and mesenteric visceral omentum were collected in tubes (BD Falcon ${ }^{\mathrm{TM}}$, San Jose, California, USA) containing RPMI 1640 medium (HiMedia Laboratories LTD, India) supplemented with L-glutamine, $100 \mathrm{UI} / \mathrm{ml}$ penicillin and $0.1 \mathrm{mg} / \mathrm{mL}$ streptomycin (Sigma Chemical Co., St. Louis, MO, USA) and kept on ice until processed.

\subsection{ADSCs isolation and expansion}

The isolation protocol used in this research was adapted from Inácio, 2011. Tissue samples were placed in petri plates (60xl0mm Rodac, USA) and weighed in analytical scale (Shimadzu, Japan). 3 mL of RPMI 1640 medium was added (Himedia PVT LTD Laboratories, India), samples were cut into small pieces using scissors and carried to mechanical dissociation by syringe needles for 5 minutes.

Tissue supernatant was removed, cells were aspirated and dissociated in $40 \mu \mathrm{m}$ cell strainer $\left(\right.$ Falcon $^{\mathrm{TM}} \mathrm{BD}$, San Jose, California, USA). Then, medium containing cells was centrifuged for $7 \mathrm{~min}$ at $400 \mathrm{x}$ g, resuspended and measured by Trypan blue staining in hemocytometer (Optik Labor, Friedrichshofen, Germany). After counting, cells were seeded in $25 \mathrm{~cm}^{2}$ flasks (TPP, Trasadingen, Switzerland) in a platting density of $9 \times 10^{4}$ cells $/ \mathrm{cm}^{2}$ with RPMI 1640 supplemented with $20 \%$ fetal bovine serum (FBS; Sigma, USA), $100 \mathrm{UI} / \mathrm{ml}$ penicillin and $0.1 \mathrm{mg} / \mathrm{mL}$ streptomycin and maintained in incubator with $5 \% \mathrm{CO}_{2}$ atmosphere at $37^{\circ} \mathrm{C}$ (Thermo Scientific HEPA Class 100, USA). The culture media exchange occurred twice or three times a week.

Alternatively, we tested an enzymatic protocol for ADSCs isolation. After weighed and dissociated in small pieces, samples were suspended in $3 \mathrm{mg} / \mathrm{mL}$ collagenase type I solution (Invitrogen, USA) and then incubated at $40^{\circ} \mathrm{C}$ water bath for $45 \mathrm{~min}$. After this time, samples were centrifuged for $\mathrm{x} \min$ at $\mathrm{x} \times \mathrm{g}$, and resulting pellet was resuspended in RPMI-1640 medium and cultivated in $25 \mathrm{~cm}^{2}$ culture flasks.

\subsection{ADSCs cryopreservation}

ADSCs (from third passage) were dissociated by trypsin and frozen in the final concentration of $10^{6}$ cells $/ \mathrm{mL}$ in freezing tubes (Eppendorf, Germany). We evaluated three cryoprotectors: dymethylsulphoxide (DMSO; concentrations: $1-10 \%$ in FBS), dimethylformamide (DMF; concentrations: $5 \%$ in FBS) and acetone $(0,8 \%)+$ formic acid $(2 \%)$ solution in FBS.

All samples were kept at $-20^{\circ} \mathrm{C}$ for $20 \mathrm{~min}$ followed by $-80{ }^{\circ} \mathrm{C}$ freezing for 30 days. Thawing was done quickly in water bath at $37^{\circ} \mathrm{C}$ and then cell viability by Trypan blue dye exclusion was analyzed at 24, 48 and 72 hours.

\subsection{Statistical analysis}

GraphPadInStat 3.0 program was used for statistical analysis. Cell viability results were analyzed by $T$ test and cryopreservation data by ANOVA. The significance limit adopted was $\mathrm{p}<0.05$. The data were presented as mean \pm standard deviation.

\section{Results}

\subsection{Isolation protocols of ADSCs - mechanical dissociation was more suitable for ADSC isolation from visceral omentum}

Tests were performed to evaluate the most appropriate method to isolate adult stem cells from adipose tissue: mechanical and enzymatic dissociation. First, we tested both techniques with adipose tissue from visceral omentum. The isolation protocol that showed the best results in ADSCs isolation was mechanical dissociation (Table 1 ). This technique was successful in 3/4 tissue samples in comparison to $1 / 4$ for enzymatic dissociation and demonstrate a higher growth rate and cell viability (data not shown). Furthermore, it has a low cost and more acceptable for use in cell therapy. For this reason, we have chosen mechanical dissociation protocol for cell isolation for different adipose tissue sources from the same donor.

\subsection{Evaluation of different adipose tissues in ADSC isolation}

Adipose tissue samples were collected from 3 sources in obese patients: visceral fat of the mesenteric region, visceral fat of the omental zone and subcutaneous (Figure 1).

The donors profiles described in Table 2 .

It was observed that the cells derived from different adipose tissues showed varied morphology and growth ratio.

Table 1. Comparison of ADSCs isolation with mechanical and enzymatic dissociation.

\begin{tabular}{ccc}
\hline Patients & $\begin{array}{c}\text { Enzymatic } \\
\text { Dissociation } \\
\text { (Collagenase I) }\end{array}$ & $\begin{array}{c}\text { Mechanical } \\
\text { Dissociation }\end{array}$ \\
\hline 1 & YES & YES \\
2 & NO & YES \\
3 & NO & YES \\
4 & NO & NO \\
\hline
\end{tabular}

YES: cells growth. NO: no growth. 


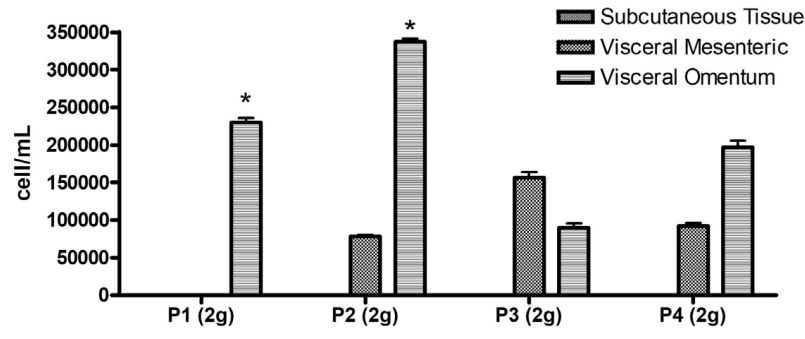

Figure 1. Comparison between different adipose tissue sources. Subcutaneous samples did not obtain data. Visceral omentum had a higher number of cells in relation to visceral mesenteric adipose tissue. $(\mathrm{p} \leq 0.05)$.
The visceral fat of the omental had the highest cell growth (Table 3 ) and first reached confluence analyzed by optic microscopy. After the 7th day of culture we could observed fibroblast-like cells attached in the flasks (Figure 2).

\subsection{ADSC cryopreservation}

The higher cell viability after freezing was obtained by visceral omentum adipose tissue. After 7 days of culture, cells settled $50 \%$ confluence. Cryopreservation data are shown in Table 4 and Figure 3.

Among the tested cryoprotectants, both DMSO and DMF maintained an ASC high viability after thawing. The concentration

Table 2. Patients profile.

\begin{tabular}{lcccc}
\hline \multicolumn{1}{c}{ Sex } & Age & Height & Weight & BMI \\
\hline Man (P1) & 34 & $1.75 \mathrm{~m}$ & $135.50 \mathrm{Kg}$ & $43.4 \mathrm{Kg} / \mathrm{m}^{2}$ \\
Man (P2) & 45 & $1.71 \mathrm{~m}$ & $123.40 \mathrm{Kg}$ & $42.2 \mathrm{Kg} / \mathrm{m}^{2}$ \\
Woman (P3) & 32 & $1.62 \mathrm{~m}$ & $108.600 \mathrm{Kg}$ & $41.38 \mathrm{Kg} / \mathrm{m}^{2}$ \\
Woman (P4) & 40 & $1.54 \mathrm{~m}$ & $103.800 \mathrm{Kg}$ & $43.77 \mathrm{Kg} / \mathrm{m}^{2}$ \\
\hline
\end{tabular}

${ }^{*} \mathrm{P}$ is passage of cell culture.

Table 3. Cell growth after 21 th day of culture.

\begin{tabular}{cccccc}
\hline \multirow{2}{*}{ Patient } & Isolated Tissue & & Isolated Tissue & & Isolated Tissue \\
\cline { 2 - 3 } \cline { 5 - 6 } & Subcutaneous & VS & Visceral Mesenteric & & Visceral Omentum \\
\hline P1 & NS & NS & & $2.45 \times 10^{5} \mathrm{cells} / \mathrm{mL}$ \\
P2 & NS & & $7 \times 10^{4}$ cells $/ \mathrm{mL}$ & & $3.15 \times 10^{5} \mathrm{cells} / \mathrm{mL}$ \\
P4 & NS & & $1.5 \times 10^{5}$ cells $/ \mathrm{mL}$ & & $1 \times 10^{5} \mathrm{cells} / \mathrm{mL}$ \\
& $1 \times 10^{5}$ cells $/ \mathrm{mL}$ & & $2 \times 10^{5} \mathrm{cells} / \mathrm{mL}$ \\
\hline
\end{tabular}

NS: Not significant.
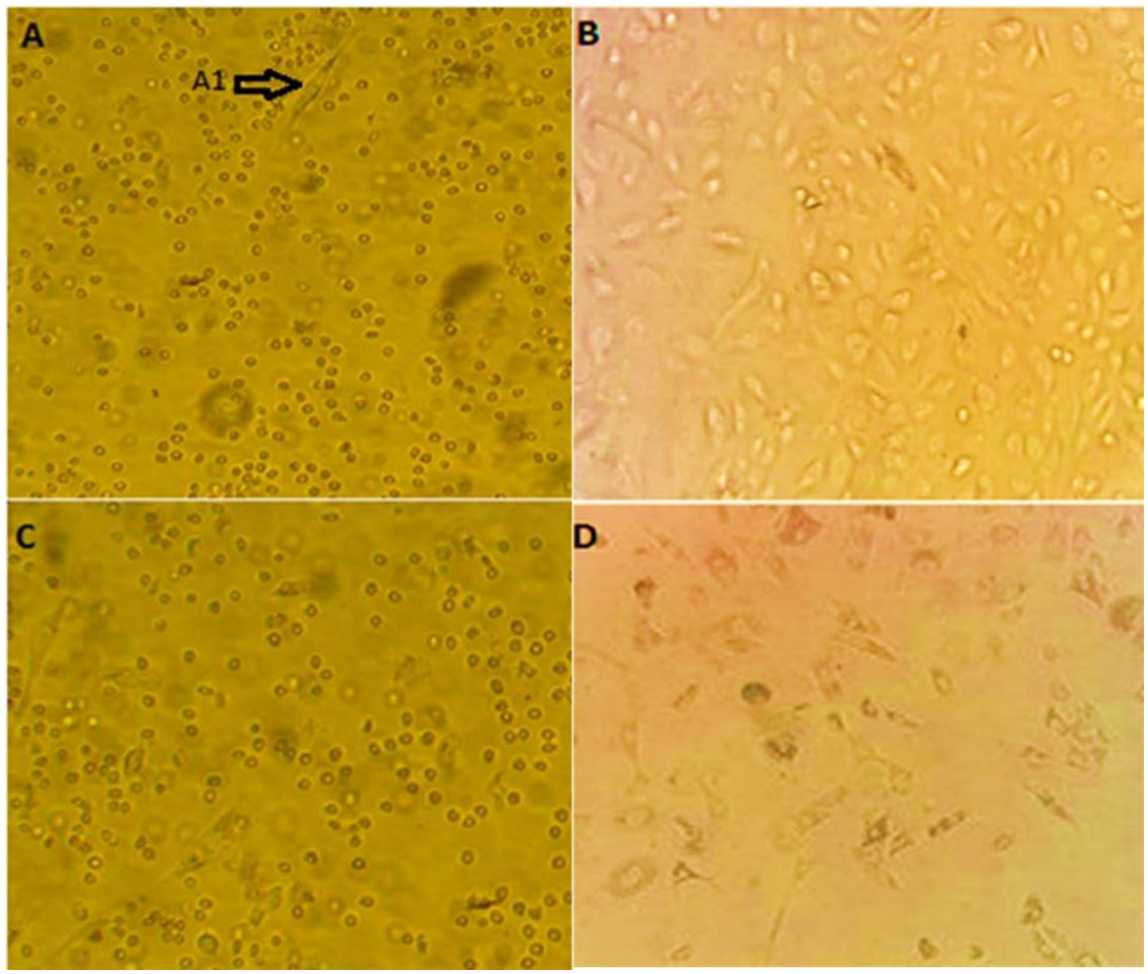

Figure 2. ASC from different human adipose tissues. A - fibroblast-like morphology. B - visceral adipose tissue of omentum. C - mesenteric visceral adipose tissue. D - subcutaneous. 
Table 4. Cell Growth after freezing with different concentrations of DMSO.

\begin{tabular}{|c|c|c|c|}
\hline Control & Cryoprotectant & Concentration \% & Cells \\
\hline \multirow{3}{*}{$8.5 \times 10^{4}$ cells $/ \mathrm{mL}$} & DMSO & 3 & $3.1 \times 10^{4}$ cells $/ \mathrm{mL}$ \\
\hline & DMSO & 4 & $3.7 \times 10^{4}$ cells $/ \mathrm{mL}$ \\
\hline & DMSO & 5 & $4.2 \times 10^{4}$ cells $/ \mathrm{mL}$ \\
\hline \multirow{3}{*}{$4.4 \times 10^{4}$ cells $/ \mathrm{mL}$} & Dimethylformamide & 3 & $2.8 \times 10^{4}$ cells $/ \mathrm{mL}$ \\
\hline & Dimethylformamide & 4 & $1.9 \times 10^{4}$ cells $/ \mathrm{mL}$ \\
\hline & Dimethylformamide & 5 & $3.6 \times 10^{4}$ cells $/ \mathrm{mL}$ \\
\hline \multirow{3}{*}{$6 \times 10^{4}$ cells $/ \mathrm{mL}$} & Formic Ac. + Acetone & 3 & $1 \times 10^{4}$ cells $/ \mathrm{mL}$ \\
\hline & Formic Ac. + Acetone & 4 & $0.5 \times 10^{4}$ cells $/ \mathrm{mL}$ \\
\hline & Formic Ac. + Acetone & 5 & $0.3 \times 10^{4}$ cells $/ \mathrm{mL}$ \\
\hline
\end{tabular}

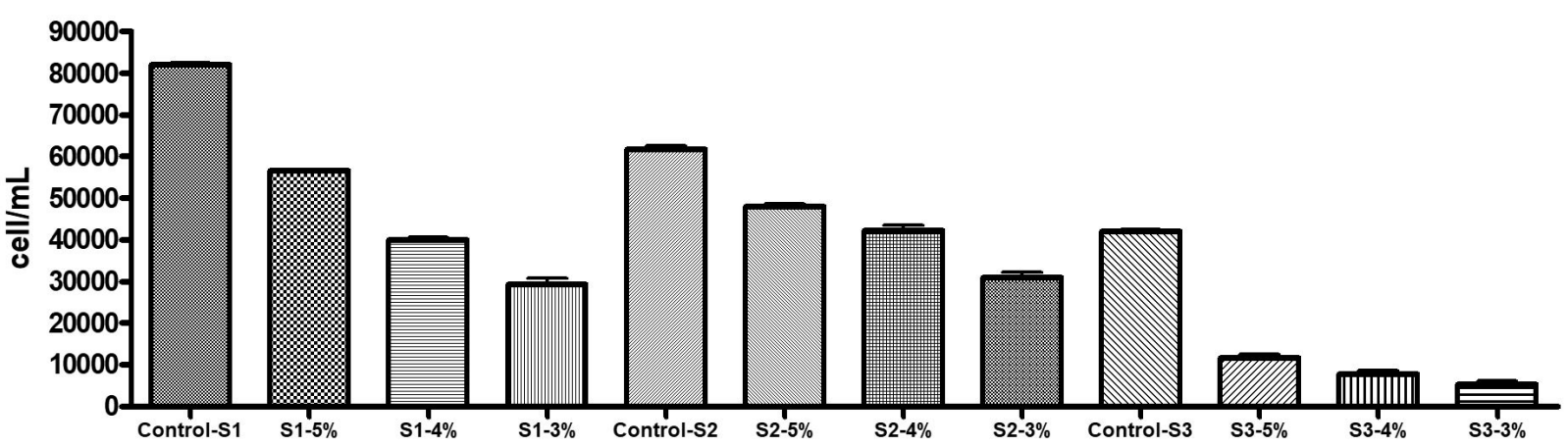

Figure 3. ASC growth after freezing and thawing. S1- DMSO solution concentrations of 5\%, 4\% and 3\%. S2 - Dimethylformamide: $5 \%, 4 \%$ and $3 \%$. S3 - Formic acid + acetone solution $(5 \%, 4 \%$ and $3 \%)(p \leq 0.05)$.

of DMSO that has been more appropriated was $5 \%$. The DMF has been also more successful at $5 \%$ concentration. None of the concentration of formic acid + acetone promoted significant cell viability.

\section{Discussion}

MSCs for application in functional tissue engineering needs to be abundantly available, harvested with minimal morbidity, cryopreserved with viability maintenance and be able to be transplanted safely and efficaciously (JANZ, DEBES, CAVAGLIERI et al., 2012). These multipotent stem cells can be isolated from various mesenchymal tissue sources in adults, most commonly bone marrow (BARRY and MURPHY, 2004). Therefore, the harvest of bone marrow stem cells has practical constraints (BUNNELL, FLAAT, GAGLIARDI et al., 2008). Based on this information, we choose to study the human adipose tissue as a source of MSCs.

Because human adipose tissue is ubiquitous and easily obtainable in large quantities from obese patients, it provide an alternative source of mesenchymal stem cells (named adipose stem cells or ASCs) for tissue regeneration and transplants (CANNON and NEDERGAARD, 2004). In recent years the prevalence of obesity has been rapidly rising throughout the Western world and along with this, the number of patients undergoing bariatric surgery has also increased significantly. Obesity presents further evidence supporting the existence of stem cells within adipose depots (GIMBLE, KATZ, BUNNELL, 2007). Recent advances in understanding the secretory capacity of adipose tissue and the role of adipokines in the development of obesity and associated disorders have added a new dimension to the study of adipose tissue biology in normal and diseased states (BAPTISTA, SILVA, PEDROSA et al., 2013).
Although studies are limited, adipose depot specific differences appear to exist with respect to stem cell content (SONODA, AOKI, UCHIHASHI et al., 2008). In our work, about 1 to $10 \mathrm{~g}$ of subcutaneous, visceral and mesenteric omentum fat were collected at bariatric surgery in obese individuals. Early studies showed that ASCs could be found in any type of white adipose tissue, including subcutaneous and omental fat (ZUK, ZHU, ASHJIAN et al., 2002).

To proceed ASCs isolation, we evaluate two methods: mechanical and enzymatic dissociation. Most research described ASCs isolation methods from lipoaspirates. The adipose tissue is digested with collagenase to break down the stroma, then filtered and centrifuged. In our study, enzymatic procedure obtained $25 \%$ of success rate. Lower result than that described by Aguiar (AGUIAR, KULIGOVSKI, COSTA et al., 2011), who used collagenase type I and II for isolating cardiac mesenchymal cell lineages and obtained $42 \%$ success. Several works do not report percentage, but describe successful separation of neurons and progenitor stem cells, described as neurospheres, using enzymatic dissociation. Our results may have been influenced considering the diet rich in fatty acids of the patients. Diets rich in fatty acids can cause decreased production of growth factors, cell adhesion and inhibit the proliferation.

Mechanical dissociation procedure was successful in $50 \%$ of the samples and then, we decided to use this technique for other adipose tissue samples, due to its lower cost and smaller influence in cells characteristics for future use in cell therapy. The selection of ASCs is based on their physical adherence to plastic tissue culture dishes (YARAK and OKAMOTO, 2010).

It was observed that the samples with the same tissue origin varied in shape of a patient to another. P2 was observed in the mesenteric visceral adipose tissue is presented in a thin 
layer over the same as $\mathrm{P} 1, \mathrm{P} 3$ and $\mathrm{P} 4$. This may represent a smaller accumulation of visceral fat that in mesenteric region.

The ability to reliably, cryopreserve and recover ASC over long times is also useful. The choice of cryoprotector used must be done carefully to avoid cell death and maintain the cells ASCs characteristics (BUNNELL, FLAAT, GAGLIARDI et al., 2008). Cryoprotectant agents, formic acid + acetone, showed no significant data in the three different concentrations. DMSO and DMF showed potential cryoprotectant action in preserving the viability of isolated stem cells. Cell cryopreservation in DMSO solution had a $49 \%$ success and DMF solution had $81 \%$. The decrease of cell viability after cryopreservation can be explained by the amount of cryopreserved cells was below $1 \times 10^{6}$, the amount recommended for cryopreservation (FULLER and PAYNTER, 1996). DMF was the most effective ASCs cryoprotectant.

Based in the ease of harvest, isolation and culture of ASC, as well as their relative abundance, it is likely that ASC will find widespread application in clinical practice in the future.

\section{References}

ABDALLAH, BM. and KASSEM, M. Human mesenchymal stem cells: from basic biology to clinical applications. Gene Therapy, 2008, vol. 15, n. 2, p. 109-116. PMid:17989700. http://dx.doi.org/10.1038/ sj.gt.3303067

AGUIAR, AM., KULIGOVSKI, C., COSTA, MTBA., STIMAMIGLIO, MA., REBELATTO, CLK., SENEGAGLIA, AC., BROFMAN, PRS., DALLAGIOVANNA, B., GOLDENBERG, S. and CORREA, A. Alkaline phosphatase-positive cells isolated from human hearts have mesenchymal stem cell characteristics. Stem Cells Discovery, 2011, vol. 1, n. 3, p. 71-80. http://dx.doi.org/10.4236/scd.2011.13008.

AHIMA, RS. and FLIER, JS. Adipose tissue as an endocrine organ. Trends in Endocrinology and Metabolism, 2000, vol. 11, n. 11, p. 327-332. PMid:10996528. http://dx.doi.org/10.1016/S10432760(00)00301-5.

BARRY, FP. and MURPHY, JM. Mesenchymal stem cells: clinical applications and biological characterization. The International Journal of Biochemistry \& Cell Biology, 2004, vol. 36, n. 4, p. 568-841. PMid:15010324. http://dx.doi.org/10.1016/j.biocel.2003.11.001.

BAPTISTA, LS., SILVA, KR., PEDROSA, CSG., SILVA, CC., CARNEIRO, JRI., ANICETO, M., COELHO, VM., TAKIYA, CM., ROSSI, MID. and BOROJEVIC, R. Adipose tissue of control and exobese patients exhibit differences in Blood Vessel content and resident mesenchymal stem cell population. Obesity Surgery, 2009, vol. 19, n. 9, p. 1304-1312. https://dx.doi.org/10.1007/s11695-009-9899-2

BLAGLIONI, S., CANTINI, G., POLI, G., FRANCALANCI, M., SQUECCO, R., DI FRANCO, A., BORGOGNI, E., FRONTERA, S., NESI, G., LIOTTA, F., LUCCHESE, M., PERIGLI, G., FRANCINI, F., FORTI, G., SERIO, M. and LUCONI, M. Functional differences in visceral and subcutaneous fat pads originate from differences in the adipose stem cell. PLoS One, 2012, vol. 7, n. 5, p e36569. http:// dx.doi.org/10.1371/journal.pone.0036569.

BUNNELL, BA., FLAAT, M., GAGLIARDI, C., PATEL, B. and RIPOLL, C. Adipose - derived stem cells: Isolation, expansion and differentiation. Methods (San Diego, Calif.), 2008, vol. 45, n. 2, p. 115-120. PMid:18593609. http://dx.doi.org/10.1016/j. ymeth.2008.03.006.

CANNON, B. and NEDERGAARD, J. Brow Adipose tissue: Functiona and Physiological Significance. Physiological Reviews, 2004, vol. 84, n. 1, p. 277-359. PMid:14715917. http://dx.doi.org/10.1152/ physrev.00015.2003.

CAPLAN, AI. and DENNIS, JE. Mesenchymal stem cells as trophic mediators. Journal of Cellular Biochemistry, 2006, vol. 98, n. 5, p. 1076-1084. PMid:16619257. http://dx.doi.org/10.1002/ jcb.20886.

FULLER, B. and PAYNTER, S. Fundamentals of cryobiology in reproductive medicine. Reproductive BioMedicine Online, 1966, vol. 9, p. 680-691. http://dx.doi.org/10.1016/S1472-6483(10)61780-4.

GIMBLE, JM., KATZ, AJ. and BUNNELL, BA. Adipose - derived stem cells for regenerative medicine. Circulation Research, 2007, vol. 100, n. 9, p. 1249-1260. PMid:17495232. http://dx.doi. org/10.1161/01.RES.0000265074.83288.09.

JANZ, FL., DEBES, AA., CAVAGLIERI, RC., DUARTE, SA., ROMÃO, CM., MORÓN, AF., ZUGAIB, M. and BYDLOWSKI, SP. Evaluation of distinct freezing methods and cryoprotectants for human amniotic fluid stem cells cryopreservation. Journal of Biomedicine \& Biotechnology, 2012, vol. 2012, p. 1-10. http://dx.doi. org/10.1155/2012/649353.

KATZ, AJ., THOLPADY, A., THOLPADY, SS., SHANG, H. and OGLE, RC. Cell surface and transcriptional characterization of human adipose-derived adherent stromal (hADAS) cells. Stem Cells (Dayton, Ohio), 2005, vol. 23, n. 3, p. 412-423. PMid:15749936. http:// dx.doi.org/10.1634/stemcells.2004-0021.

ROGER, PC., MEACHAM, LR., OEFFINGER, KC., HENRY, DW. and LANGE, BJ. Obesity in pediatric oncology. Pediatric Blood o Cancer, 2005, vol. 45, n. 7, p. 881-891. PMid:16035086. http:// dx.doi.org/10.1002/pbc.20451.

SAKAGUCHI, Y., SEKIYA, I., YAGISHITA, K. and MUNETA, T. Comparasion of human stem cells derived from varius mesenchymal tissues: superiority of synovium as a cell source. Arthritis and Rheumatism, 2005, vol. 52, p. 2521-2529. PMid:16052568. http:// dx.doi.org/10.1002/art.21212.

SONODA, E., AOKI, S., UCHIHASHI, K., SOEJIMA, H., KANAJI, S., IZUHARA, K., SATOH, S., FUJITANI, N., SUGIHARA, H. and TODA, S. A new organotypic culture of adipose tissue fragments maintains viable mature adipocytes for a long term, together with development of immature adipocytes and mesenchymal stem cells-like cells. Endocrinology, 2008, vol. 149, n. 10, p. 149-153. PMid:18535101. http://dx.doi.org/10.1210/en.2008-0525.

TODA, S., UCHIHASHI, K., AOKI, S., SONODA, E., YAMASAKI, F., PIAO, M., OOTANI, A., YONEMITSU, N. and SUGIHARA, $\mathrm{H}$. Adipose tissue - organotypic culture system as a promising model for studying adipose tissue biology and regeneration. Organogenesis, 2009, vol. 5, n. 5, p. 50-56. PMid:19794899. http://dx.doi. org/10.4161/org.5.2.8347.

YARAK, S. and OKAMOTO, OK. Human adipose-derived stem cells: current challenges and clinical perspectives. Anais Brasileiros de Dermatologia, 2010, vol. 85, n. 5, p. 647-656. PMid:21152789. http://dx.doi.org/10.1590/S0365-05962010000500008.

ZUK, P., ZHU, M., ASHJIAN, P., DE UGARTE, DA., HUANG, JI., MIZUNO, H., ALFONSO, ZC., FRASER, JK., BENHAIM, P. and HEDRICK, MH. Human adipose tissue is a source of multipotent stem cells. Molecular Biology of the Cell, 2002, vol. 13, n. 12, p. 4279-4295. PMid:12475952. http://dx.doi.org/10.1091/mbc. E02-02-0105. 